\title{
Faunistic analysis of the species of Anastrepha Schiner (Diptera: Tephritidae) in three municipalities of the state of Roraima, Brazil
}

\author{
Marsaro Júnior, AL. ${ }^{a}$, Nascimento, DB. ${ }^{b}$, Ronchi-Teles, $B .^{c}$ and Adaime, $R .^{d *}$ \\ ${ }^{a}$ Embrapa Trigo, Rod. BR 285, Km 294, CP 451, CEP 99001-970, Passo Fundo, RS, Brazil \\ 'Programa de Pós-graduação em Biodiversidade Tropical, Universidade Federal do Amapá - UNIFAP, \\ Rod. JK, Km 4, CEP 68902-280, Macapá, AP, Brazil \\ 'Instituto Nacional de Pesquisas da Amazônia - INPA, \\ Av. André Araújo, 2936, Aleixo, CEP 69060-001, Manaus, AM, Brazil \\ dEmbrapa Amapá, Rod. JK, Km 5, 2600, CEP 68903-419, Macapá, AP, Brazil \\ *e-mail: ricardo.adaime@embrapa.br
}

Received August 11, 2011 - Accepted January 23, 2012 - Distributed November 30, 2012

(With 3 figures)

\begin{abstract}
The purpose of this work was to describe the population patterns of Anastrepha in three municipalities of the state of Roraima, Brazil, via faunistic analysis. Weekly collections were performed from January through December 2008, using McPhail traps containing 5\% hydrolysed protein, in domestic orchards in the municipalities of Boa Vista, Bonfim and Pacaraima. We captured 301 females of Anastrepha in Boa Vista, 212 in Bonfim, and 167 in Pacaraima. Boa Vista presented the highest species richness $(S=10)$ and Pacaraima the lowest $(S=4)$. Anastrepha striata was the predominant species in Boa Vista (47.18\%) and Pacaraima (65.87\%), whereas A. obliqua predominated in Bonfim (46.23\%). Boa Vista presented the highest Shannon-Wiener diversity index $\left(H^{\prime}=1.19\right)$ and Margalef index $(\alpha=1.58)$, and Bonfim presented the highest Pielou's evenness index $\left(\mathrm{J}^{\prime}=0.69\right)$. In Pacaraima the cumulative curves reached stability, confirming that the observed and expected species richness were the same. In the other two municipalities, the curves showed a moderate growth, suggesting that the sampling effort was not sufficient to produce an accurate depiction of species richness. In this study, Anastrepha zernyi is reported for the first time in Roraima.
\end{abstract}

Keywords: Amazon, diversity, faunistic index, fruit flies.

\section{Análise faunística das espécies de Anastrepha Schiner (Diptera: Tephritidae) em três municípios do estado de Roraima, Brasil}

\section{Resumo}

Este trabalho objetivou caracterizar populações de Anastrepha spp. em três municípios do estado de Roraima, por meio de uma análise faunística. Foram realizadas coletas semanais, de janeiro a dezembro de 2008, utilizando-se armadilhas tipo McPhail contendo proteína hidrolisada a 5\%, em pomares domésticos nos municípios de Boa Vista, Bonfim e Pacaraima. Foram capturadas 301 fêmeas de Anastrepha em Boa Vista, 212 em Bonfim e 167 em Pacaraima. Boa Vista apresentou maior riqueza de espécies $(S=10)$ e Pacaraima a menor $(S=4)$. Anastrepha striata predominou em Boa Vista (47,18\%) e Pacaraima (65,87\%), e A. obliqua em Bonfim (46,23\%). Boa Vista apresentou o maior índice de diversidade de Shannon-Wiener $\left(H^{\prime}=1,19\right)$ e de Margalef $(\alpha=1,58)$, e Bonfim apresentou o maior índice de equitabilidade de Pielou $\left(\mathrm{J}^{\prime}=0,69\right)$. Em Pacaraima as curvas acumulativas se estabilizaram, confirmando que a riqueza observada foi equivalente à esperada. Nos demais municípios as curvas apresentaram um crescimento moderado o que sugere que o esforço amostral não foi suficiente para amostrar a riqueza de espécies. Neste estudo, Anastrepha zernyi é registrada pela primeira vez em Roraima.

Palavras-chave: Amazônia, diversidade, índice faunístico, moscas-das-frutas. 


\section{Introduction}

The state of Roraima is located in the extreme north of the Brazilian Amazon, bordering Venezuela, Guyana, and the Brazilian states of Amazonas and Pará. The first studies on Anastrepha species in Roraima began in the 1990s with Rafael (1991) and Ronchi-Teles et al. (1995), who added new information on the species richness of Anastrepha in the state (Marsaro Júnior et al., 2011).

Seventeen species of Anastrepha have been reported in the region up to the present time and six species of parasitoids have also been reported in Roraima, namely five Braconidae and one Figitidae (Marsaro Júnior et al., 2011). In spite of this, no faunistic analyses have been completed in Roraima as yet.

To date, very few faunistic analyses have been completed on the diversity and species richness of fruit flies in the Brazilian Amazon. The only such study at present is the work of Bomfim et al. (2007), who compared the fruit fly faunas of domestic orchards and native forests in two municipalities of the state of Tocantins. The literature on faunistic analysis of fruit flies is scarce and limited to studies conducted in Brazil, most notably those by Canal et al. (1998) in the state of Minas Gerais; Garcia and Corseuil (1998) in the state of Rio Grande do Sul; UchôaFernandes et al. (2003) in the center of Mato Grosso do Sul state; Garcia et al. (2003) and Alberti et al. (2009) in the state of Santa Catarina; Canesin and Uchôa-Fernandes (2007) in the south of the state of Mato Grosso do Sul; Aguiar-Menezes et al. (2008) in the state of Rio de Janeiro and Dutra et al. (2009) in the state of Bahia.

These types of studies are fundamental to the description of fruit fly diversity and distribution in the Brazilian Amazon, a topic on which very little information is presently available. The purpose of this work was to describe the population patterns of Anastrepha species in three municipalities of the state of Roraima, Brazil, via faunistic analysis.

\section{Material and Methods}

\subsection{Survey sites}

The work was completed in three municipalities of the state of Roraima (four traps in Boa Vista and two traps each in Bonfim and Pacaraima). All of the traps were installed at an approximate height of $1.70 \mathrm{~m}$ in household orchards of small private properties where the availability of host plants was very similar, as well as in the Embrapa main facility in Boa Vista (Table 1).

Each of the orchards covered an approximate area of 1 hectare and contained fruit trees that were about 10 years old. The plant species cultivated in the orchards are: Brazilian guava (Psidium guineense Sw.), Guava (Psidium guajava L.), Hog plum (Spondias mombin L.), Jocote (Spondias purpurea L.), Mango (Mangifera indica L.), Pitanga (Eugenia uniflora L.), Star fruit (Averrhoa carambola L.), Barbados cherry (Malpighia punicifolia L.), Indian jujube (Zizyphus mauritiana Lam.), Ice-creambean (Inga edulis Mart.), Cashew (Anacardium occidentale L.), and Abiu [Pouteria caimito (Ruiz \& Pav.) Radlk.]. Unidentified native plant species of the cerrado biome were also present, some of which might potentially be host plants for fruit flies.

The vegetation in the three municipalities is characteristic of the cerrado biome, and the region is subject to a welldefined dry period between December and March. The most accurate meteorological information about the region is available through the weather station in Boa Vista. Mean rainfall as reported by this station is $1,655 \pm 408 \mathrm{~mm}$. year $^{-1}$. Roughly $9 \%$ of total rainfall takes place at the peak of the dry season (December-March), and 70\% at the peak of the rainy season (May-August) (Barbosa, 1997; Araújo et al., 2001).

\subsection{Insect collection and identification}

The collections were performed using McPhail plastic traps, each baited with $400 \mathrm{~mL}$ of food bait containing $5 \%$ hydrolysed corn protein (BioAnastrepha ${ }^{\circledR}$ ), and stabilised with borax. Collections were conducted weekly from January through December 2008. A total of 53 samples were taken per collection site.

The captured insects were stored in labelled containers of $70 \%$ ethanol and transported to the Laboratório de Entomologia at Embrapa Roraima in Boa Vista, where they were identified. The Anastrepha females were then transported to the Instituto Nacional de Pesquisas da Amazônia (INPA) and to Embrapa Amapá, where they were identified to species level according to the key by Zucchi (2000). Voucher specimens were deposited in the collections of the Laboratory of Entomology at Embrapa Amapá, in Macapá, and INPA, in Manaus.

Table 1. Surveyed localities and respective points of collection, altitudes, and plants where McPhail traps were installed. (January through December 2008).

\begin{tabular}{cccccc}
\hline City & Traps (n) & Latitude & Longitude & Altitude & Plants \\
\hline Boa Vista & 1 & $02^{\circ} 45^{\prime} 24.1^{\prime \prime} \mathrm{N}$ & $60^{\circ} 42^{\prime} 54.0^{\prime \prime} \mathrm{W}$ & $88 \mathrm{~m}$ & Guava \\
& 1 & $02^{\circ} 51^{\prime} 43.4^{\prime \prime} \mathrm{N}$ & $60^{\circ} 40^{\prime} 06.2^{\prime \prime} \mathrm{W}$ & $102 \mathrm{~m}$ & Barbados cherry \\
& 1 & $02^{\circ} 57^{\prime} 03.6^{\prime \prime} \mathrm{N}$ & $60^{\circ} 42^{\prime} 21.3^{\prime \prime} \mathrm{W}$ & $90 \mathrm{~m}$ & Barbados cherry \\
& 1 & $02^{\circ} 45^{\prime} 25.0^{\prime \prime} \mathrm{N}$ & $60^{\circ} 43^{\prime} 47.7 ” \mathrm{~W}$ & $74 \mathrm{~m}$ & Cashew \\
Bonfim & 1 & $03^{\circ} 21^{\prime} 39.2^{\prime \prime} \mathrm{N}$ & $59^{\circ} 50^{\prime} 00.5^{\prime \prime} \mathrm{W}$ & $105 \mathrm{~m}$ & Barbados cherry \\
& 1 & $03^{\circ} 22^{\prime} 47.0^{\prime \prime} \mathrm{N}$ & $59^{\circ} 48^{\prime} 52.5^{\prime \prime} \mathrm{W}$ & $95 \mathrm{~m}$ & Cashew \\
Pacaraima & 1 & $04^{\circ} 29^{\prime} 19.7^{\prime \prime} \mathrm{N}$ & $61^{\circ} 07^{\prime} 52.0^{\prime \prime} \mathrm{W}$ & $931 \mathrm{~m}$ & Guava \\
& 1 & $04^{\circ} 28^{\prime} 52.1^{\prime \prime} \mathrm{N}$ & $61^{\circ} 08^{\prime} 51.3^{\prime \prime} \mathrm{W}$ & $942 \mathrm{~m}$ & Mango \\
\hline
\end{tabular}




\subsection{Data analysis}

Fruit fly diversity was assessed through species richness values $(\mathrm{S})$ and the species diversity indexes of Shannon-Wiener (H') and Margalef $(\alpha)$, as well as Pielou's evenness index (J'), all calculated using the Anafau software (Moraes et al., 2003). To assess whether the sampling effort was sufficient to sample all of the existing species at the collection sites, we used the following estimators of species richness: Chao 1 (first-order Chao), Jack 2 (secondorder Jackknife) and Bootstrap, using the Estimate S 8.0 software and running 1000 randomisations (Colwell, 2006).

The faunistic analysis of Anastrepha species was conducted according to Silveira-Neto et al. (1976). The following parameters were estimated: frequency, dominance, abundance, and constancy, using the Anafau software (Moraes et al., 2003).

Frequency: The number of individuals of one species divided by the total number of individuals in the sample.

Dominance: The ratio given by the number of individuals of a given species divided by the number of individuals of all collected species. A species is considered dominant when its frequency is higher than $1 / \mathrm{S}$, where $\mathrm{S}$ is the total number of species in the community. Species classification according to dominance: Super-dominant (sd): number of individuals is higher than the upper limit of the $5 \%$ confidence interval (CI). Dominant (d): number of individuals is within the range of the $5 \% \mathrm{CI}$. Non-dominant (nd): number of individuals is lower than the lower limit of the $5 \% \mathrm{CI}$.

Abundance: Refers to the number of individuals of a given taxonomical category per unit of surface or volume. Abundance can vary over time and space. Species abundance was classified into five categories, as follows: super-abundant (sa): number of individuals is higher than the upper limit of the $1 \% \mathrm{CI}$; very abundant (va): number of individuals is situated between the upper limits of the $5 \%$ and $1 \%$ confidence intervals; common (c): number of individuals is within the 5\% CI range; dispersed (d): number of individuals is situated between the lower limits of the $5 \%$ and $1 \%$ confidence intervals, and rare (r): number of individuals is lower than the lower limit of the $1 \% \mathrm{CI}$.

Constancy: Percentage of samples in which a given species is present. Species constancy was classified into three categories: constant $(\mathrm{w})$ : when the species was present in more than $50 \%$ of collections; accessory (y): when the species was present in $25 \%$ to $50 \%$ of collections; accidental (z): when the species was present in less than $25 \%$ of the collections.

\section{Results}

\subsection{Fruit flies species and diversity}

A total of 301, 212, and 167 females of Anastrepha species were collected respectively in the municipalities of Boa Vista, Bonfim, and Pacaraima, comprising a total of 11 species: A. striata Schiner, 1868; A. obliqua (Macquart, 1835); A. zenildae Zucchi, 1979; A. distincta Greene, 1934; A. bahiensis Lima, 1937; A. turpiniae Stone, 1942; A. serpentina (Wiedemann, 1830); A. sororcula Zucchi, 1979; A. flavipennis Greene, 1934; A. zernyi Lima, 1934; and Anastrepha sp. (Table 2). The municipality of Boa Vista presented the highest species richness $(\mathrm{S}=10)$ and Pacaraima presented the lowest $(\mathrm{S}=4)$.

Table 2. Faunistic analysis of Anastrepha species captured with McPhail traps in three municipalities of the state of Roraima, Brazil (January through December 2008).

\begin{tabular}{|c|c|c|c|c|c|c|c|c|c|c|c|c|c|c|c|}
\hline \multirow{2}{*}{ Species } & \multicolumn{5}{|c|}{ Boa Vista } & \multicolumn{5}{|c|}{ Bonfim } & \multicolumn{5}{|c|}{ Pacaraima } \\
\hline & $\mathbf{N}$ & $\mathbf{F}$ & $\mathbf{A}$ & $\mathbf{C}$ & D & $\mathbf{N}$ & $\mathbf{F}$ & $\mathbf{A}$ & $\mathbf{C}$ & D & $\mathbf{N}$ & $\mathbf{F}$ & $\mathbf{A}$ & $\mathbf{C}$ & D \\
\hline A. striata & 142 & 47.18 & sa & $\mathrm{w}$ & $\mathrm{sd}$ & 58 & 27.36 & $\mathrm{c}$ & $\mathrm{w}$ & $\mathrm{d}$ & 110 & 65.87 & va & $\mathrm{w}$ & $\mathrm{d}$ \\
\hline A. obliqua & 110 & 36.55 & $\mathrm{sa}$ & $\mathrm{w}$ & $\mathrm{sd}$ & 98 & 46.23 & va & $\mathrm{w}$ & $\mathrm{d}$ & 47 & 28.14 & va & $\mathrm{y}$ & $\mathrm{d}$ \\
\hline A. zenildae & 4 & 1.33 & va & $\mathrm{y}$ & nd & 0 & - & - & - & - & 3 & 1.8 & va & $\mathrm{y}$ & nd \\
\hline A. distincta & 35 & 11.63 & sa & $\mathrm{y}$ & sd & 54 & 25.47 & $\mathrm{c}$ & $\mathrm{y}$ & $\mathrm{d}$ & 7 & 4.14 & va & $\mathrm{y}$ & $\mathrm{d}$ \\
\hline A. bahiensis & 1 & 0.33 & $\mathrm{c}$ & $\mathrm{y}$ & nd & 0 & - & - & - & - & 0 & - & - & - & - \\
\hline A. turpiniae & 1 & 0.33 & $\mathrm{c}$ & $\mathrm{y}$ & nd & 0 & - & - & - & - & 0 & - & - & - & - \\
\hline A. serpentina & 5 & 1.66 & va & $\mathrm{y}$ & nd & 0 & - & - & - & - & 0 & - & - & - & - \\
\hline A. sororcula & 1 & 0.33 & $\mathrm{c}$ & $\mathrm{y}$ & nd & 1 & 0.47 & $\mathrm{~d}$ & $\mathrm{z}$ & nd & 0 & - & - & - & - \\
\hline A. flavipennis & 1 & 0.33 & $\mathrm{c}$ & $\mathrm{y}$ & nd & 0 & - & - & - & - & 0 & - & - & - & - \\
\hline A. zernyi & 1 & 0.33 & $\mathrm{c}$ & $\mathrm{y}$ & nd & 0 & - & - & - & - & 0 & - & - & - & - \\
\hline Anastrepha sp. & 0 & - & - & - & - & 1 & 0.47 & $\mathrm{~d}$ & $\mathrm{z}$ & nd & 0 & - & - & - & - \\
\hline Total & 301 & & & & & 212 & & & & & 167 & & & & \\
\hline S & 10 & & & & & 5 & & & & & 4 & & & & \\
\hline $\mathrm{H}^{\prime}$ & 1.19 & & & & & 1.11 & & & & & 0.84 & & & & \\
\hline $\mathrm{J}^{\prime}$ & 0.52 & & & & & 0.69 & & & & & 0.6 & & & & \\
\hline$\alpha$ & 1.58 & & & & & 0.75 & & & & & 0.59 & & & & \\
\hline
\end{tabular}

$\mathrm{N}=$ number of captured Anastrepha (females). $\mathrm{F}=$ relative frequency (\%). A = abundance: sa (super-abundant), va (very abundant), c (common), d (dispersed). C = constancy: w (constant), y (accessory), z (accidental). $\mathrm{D}=$ dominance: sd (superdominant), d (dominant), nd (non-dominant). - = no specimens were captured. $\mathrm{S}$ = richness; H' = Shannon-Wiener diversity index; J' = Pielou's evenness index; and $\alpha=$ Margalef diversity index. 
Three species (Anastrepha striata, Anastrepha obliqua and Anastrepha distincta) were captured in all municipalities. A. striata was the predominant species in Boa Vista (47.18\%), where it was super-dominant and super-abundant, and in Pacaraima (65.87\%), where it was dominant and very abundant. A. obliqua was the predominant species in Bonfim (46.23\%), where it was dominant and very abundant (Table 2).

The municipality of Boa Vista presented the highest Shannon-Wiener diversity index (H'=1.19) and Margalef's index $(\alpha=1.58)$. The municipality of Bonfim presented the highest Pielou's evenness index ( $\left.\mathrm{J}^{\prime}=0.69\right)$ (Table 2).

A total of 301 females of Anastrepha were collected in Boa Vista, with an observed richness of 10 species. The estimated richness values in Boa Vista were a minimum of 12 (bootstrap) and a maximum of 18 species (Jackknife 2) (Figure 1). In Bonfim, we obtained 212 fruit fly females. Both the observed and minimum estimated richnesses in Bonfim were five species (Chao 1) and the maximum estimated richness was seven species (Jackknife 2) (Figure 2). In Pacaraima, we obtained 167 fruit fly females. Both the observed and estimated richnesses in Pacaraima were four species, across all indexes (Figure 3).

\section{Discussion}

\subsection{Richness and diversity of fruit fly species}

The number of collected samples was the same (53) in all municipalities. Among the municipalities where the same sampling effort was applied (Pacaraima and Bonfim), the highest species richness was observed in Bonfim $(S=5)$.
Anastrepha striata was the predominant species in Boa Vista and Pacaraima. In the latter municipality, A. striata was dominant and presented the highest relative frequency $(65.87 \%$ ), as compared to $28.14 \%$ recorded for A. obliqua. This indicates that $A$. striata is well adapted to the higher altitudes covered in this work (931-942 m above sea level, compared to 74-102 $\mathrm{m}$ of altitude in Boa Vista). According to Aluja (1994), the dominance of a species is influenced by ecological bases (host plant, richness, and diversity) and by altitudinal gradient. For example, in mango orchards at $1,100 \mathrm{~m}$ above sea level in Mexico, $30 \%$ of all collected individuals of 14 species were Anastrepha ludens (Loew, 1873). At lower altitudes (680 m), among 12 captured species, only $4 \%$ of individuals were A. ludens. In this work, Anastrepha striata was also the only constant species in all three municipalities, i.e., it was present in more than $50 \%$ of collections at all three sites. These results indicate that $A$. striata can be found in great abundance in the region through most of the year, emphasizing its relevance in the state of Roraima. These data corroborate the results of Silva et al. (2011), which reported $A$. striata as the most widely distributed fruit fly species in the state of Amapá.

Anastrepha obliqua was predominant in the municipality of Bonfim. In a similar work conducted in the state of Tocantins, Bomfim et al. (2007) reported A. obliqua as the most abundant species and Ronchi-Teles and Silva (2005) confirmed it as the most relevant species in the state of Amazonas. However, it should be noted that in the municipality of Bonfim, the traps were installed on cashew and Barbados cherry trees, the latter being a known host of A. obliqua. Moreover, neither of these plant species has been reported as a host of $A$. striata in Roraima up to the

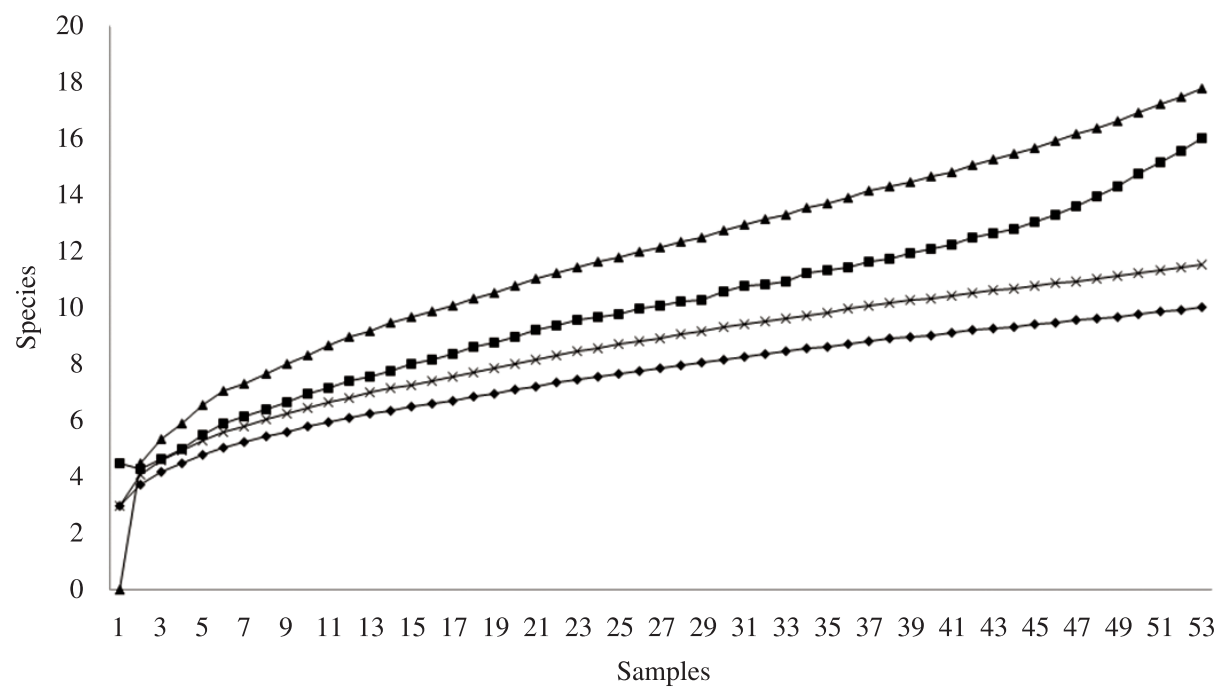

$\longrightarrow$ Observed richness $\rightarrow$ Chao $1 \multimap$ Jackknife $2 \rightarrow$ Bootstrap

Figure 1. Expected and observed species richness of Anastrepha (Diptera: Tephritidae) captured with McPhail traps in the Municipality of Boa Vista, Roraima, Brazil (January through December 2008). 


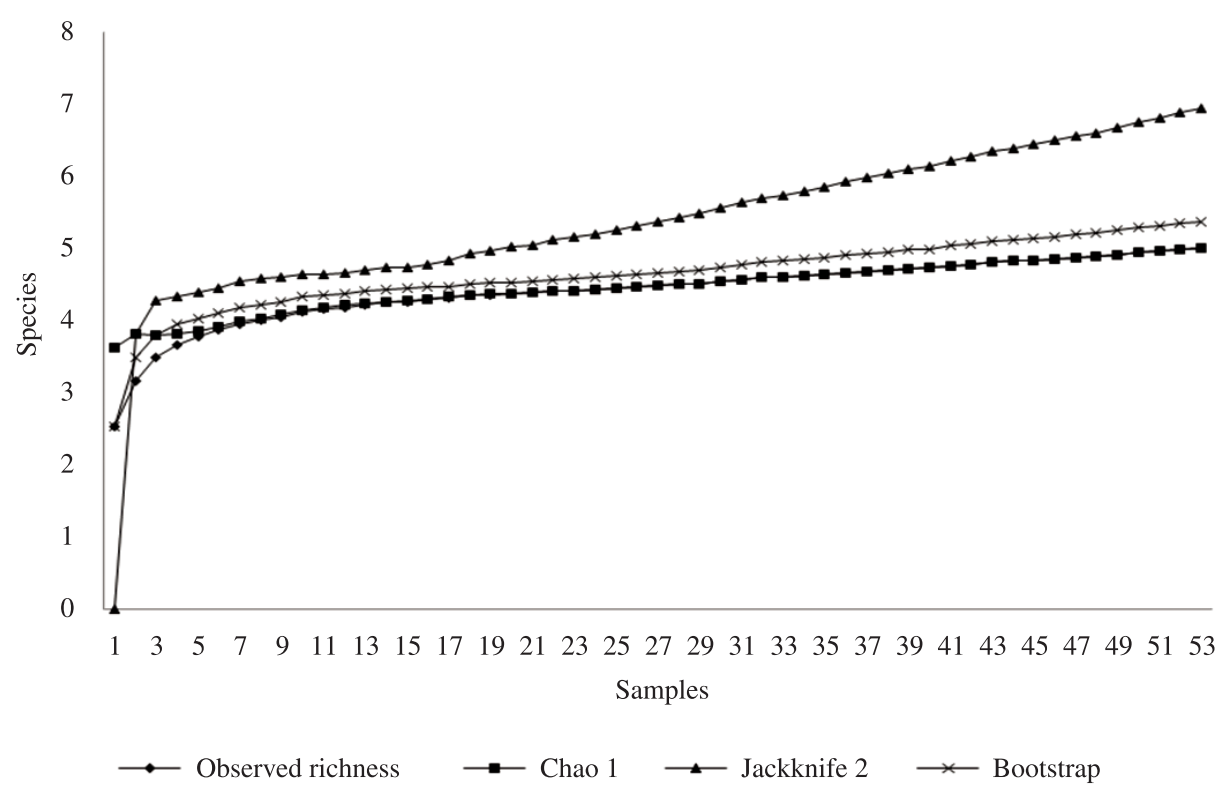

Figure 2. Expected and observed species richness of Anastrepha (Diptera: Tephritidae) captured with McPhail traps in the Municipality of Bonfim, Roraima, Brazil (January through December 2008).

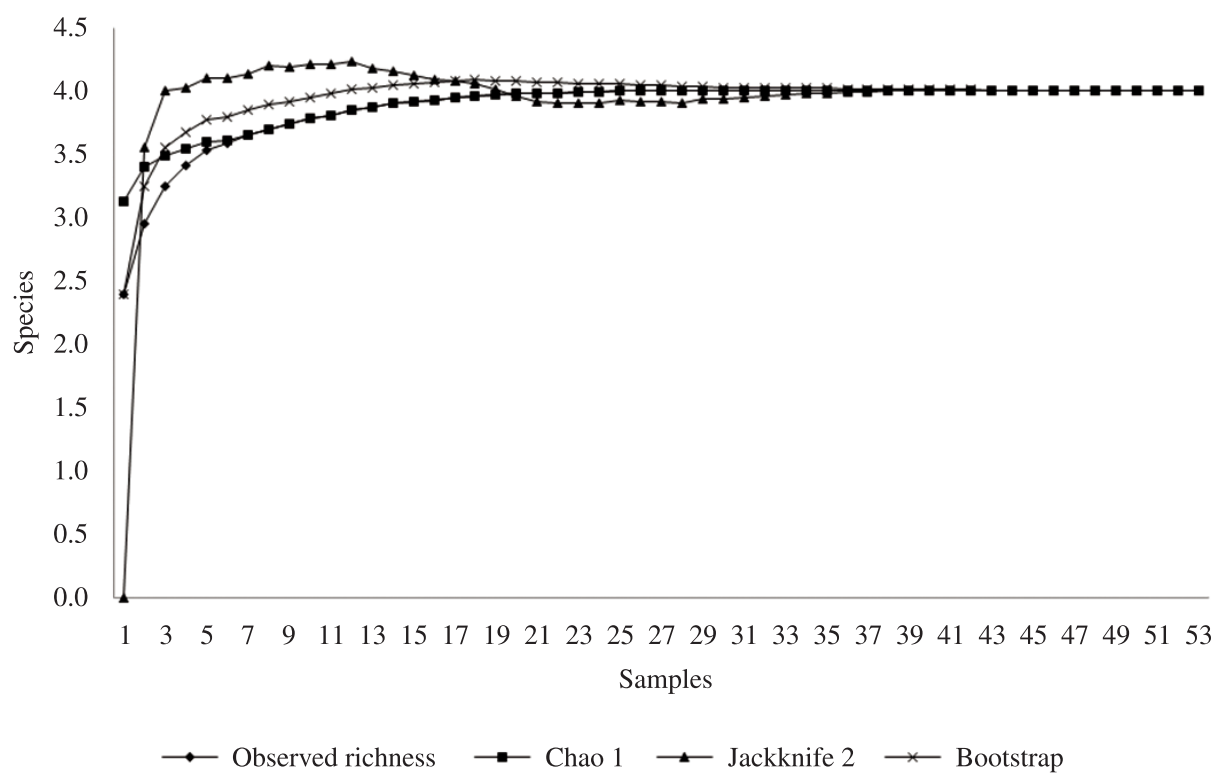

Figure 3. Expected and observed species richness of Anastrepha (Diptera: Tephritidae) captured with McPhail traps in the Municipality of Pacaraima, Roraima, Brazil (January through December 2008).

present date (Marsaro Júnior et al., 2011). This may have contributed to the lower relative frequency and smaller number of individuals of A. striata collected in Bonfim.

The higher Shannon-Wiener (H') and Margalef $(\alpha)$ indexes found in Boa Vista confirmed a higher species richness at this site (10 species), compared to the other municipalities. However, the lower evenness index found in Boa Vista was a result of the higher frequency of two species, namely A. striata and A. obliqua. According to Aluja et al. (1996), it is common to find several species of fruit flies in a same orchard, but with only one or two dominant species representing more than $90 \%$ of all flies captured in traps.

The highest evenness index was observed in the municipality of Bonfim; among the five species captured at that site, A. obliqua, A. striata and A. distincta presented 
the highest levels of uniformity among individuals of their respective species; the three species collectively accounted for roughly $99 \%$ of all captured individuals. Anastrepha distincta was the third most relevant species, present in the three municipalities along with A. striata and A. obliqua.

In Boa Vista and Bonfim, the observed species richness was lower than expected; the cumulative curves of species showed a moderate growth, suggesting that the sampling effort was not sufficient to produce an accurate depiction of species richness in these municipalities. This therefore indicates that additional studies are required in the respective geographical areas.

In Pacaraima the cumulative curves reached stability, confirming that the observed and expected species richnesses were the same, and hence the sampling effort was sufficient to sample Anastrepha species diversity.

In this study, Anastrepha zernyi was reported for the first time in Roraima. The only previous report of the species in the Brazilian Amazon was in the state of Amazonas, where its host or hosts are still unknown (Zucchi et al., 2011). One female individual of Anastrepha captured in the municipality of Bonfim was not identified and is probably a new species.

\section{Conclusions}

The faunistic analysis of Anastrepha performed in the three municipalities showed that A. striata, A. obliqua and $A$. distincta are the most frequent species, which indicates that they are well adapted to this environment. Considering these three species of fruit fly (the only ones collected in all the studied municipalities) and the fruit tree species found in the orchards at the chosen sites, we may infer that these plants - which have already been reported as hosts of Anastrepha spp. in Roraima and other Brazilian states - have contributed to the presence of fruit flies in the studied orchards. However, none of these fruit tree species has, up to the present time, been reported as a host of A. turpiniae, A. flavipennis or A. zernyi in Roraima. There are likely to be native cerrado plants that serve as hosts for these species of Anastrepha.

Studies of this nature are essential for a better understanding of the diversity and distribution of Anastrepha in the Amazon region, but the results are not conclusive. Hence the importance of additional research to corroborate these results in this unique region of Brazil.

Acknowledgements - To CNPq for the Research Productivity Fellowships granted to RA. To the biologist, M.Sc. Ezequiel da Glória de Deus, for contributions to the original manuscripts of this work

\section{References}

AGUIAR-MENEZES, EL., SOUZA, AS., LIMA-FILHO, M., BARROS, HC., FERRARA, FAA. and MENEZES, EB., 2008. Análise faunística de moscas-das-frutas (Diptera: Tephritidae) nas regiões Norte e Noroeste do Estado do Rio de Janeiro. Neotropical Entomology, vol. 37, no. 1, p. 8-14. http://dx.doi.org/10.1590/ S1519-566X2008000100002
ALBERTI, S., GARCIA, FRM. and BOGUS, GM., 2009. Moscasdas-frutas (Diptera: Tephritidae) em pomares de pessegueiro e maracujazeiro no município de em Iraceminha, Santa Catarina. Ciência Rural, vol. 39, no. 5, p. 1565-1568. http://dx.doi. org/10.1590/S0103-84782009005000077

ALUJA, M., 1994. Bionomics and management of Anastrepha. Annual Review of Entomology, vol. 39, p. 155-178.

ALUJA, M., CELEDONIO-HURTADO, H., LIEDO, P., CABRERA, M., CASTILLO, F., GUILLÉN, J. and RIOS, E. 1996. Seasonal population fluctuation and ecological implications for management of Anastrepha fruit flies (Diptera: Tephritidae) in commercial mango orchards in southern Mexico. Journal of Economic Entomology, vol. 89, p. 654-667.

ARAÚJO, WF., ANDRADE-JÚNIOR, AS., MEDEIROS, RD. and SAMPAIO, RA. 2001. Precipitação pluviométrica mensal provável em Boa Vista, Estado de Roraima, Brasil. Revista Brasileira de Engenharia Agrícola e Ambiental, vol. 5, no. 3, p. 563-567. http://dx.doi.org/10.1590/S1415-43662001000300032

BARBOSA, RI. 1997. Distribuição das chuvas em Roraima. In BARBOSA, RI., FERREIRA, EJG., CASTELLÓN, EG. (Ed.). Homem, ambiente e ecologia no Estado de Roraima. Manaus: INPA. p. 325-335.

BOMFIM, DA., UCHÔA-FERNANDES, MA. and BRAGANÇA, MAL., 2007. Biodiversidade de moscas-das-frutas (Diptera, Tephritoidea) em matas nativas e pomares domésticos de dois municípios do Estado do Tocantins, Brasil. Revista Brasileira de Entomologia, vol. 51, p. 217-223. http://dx.doi.org/10.1590/ S0085-56262007000200012

CANAL, NA., ALVARENGA, CD. and ZUCCHI, RA. 1998. Análise faunística de espécies de mosca-das-frutas (Dip., tephritidae) em minas gerais. Scientia Agricola, vol. 55, no. 1, p. 15-25.

CANESIN, A. and UCHÔA-FERNANDES, MA., 2007.Análise faunística e flutuação populacional de moscas-das-frutas (Diptera: Tephritidae) em um fragmento de floresta semidecídua em Dourados, Mato Grosso do Sul, Brasil. Revista Brasileira de Zoologia, vol. 24, no. 1, p. 185-190. http://dx.doi.org/10.1590/ S0101-81752007000100023

COLWELL, RK., 2006. Estimates: Statistical estimation of richness and shared species from samples. version 8.0. Available from: <puri.oclc.org/estimates>.

DUTRA, VS., SANTOS, MS., SOUZA-FILHO, ZA., ARAÚJO, EL. and SILVA, JG., 2009. Faunistic analysis of Anastrepha spp. (Diptera: Tephritidae) on a Guava Orchard under organic management in the Municipality of Una, Bahia, Brazil. Neotropical Entomology, vol. 38, p. 133-138. http://dx.doi.org/10.1590/ S1519-566X2009000100015

GARCIA, FRM. and CORSEUIL, E., 1998. Análise faunística de moscas-das-frutas (Diptera, Tephritidae) em pomares de pessegueiro em Porto Alegre, Rio Grande do Sul. Revista Brasileira de Zoologia, vol. 15, p. 1111-1117.

GARCIA, FRM., CAMPOS, JV. and CORSEUIL, E., 2003. Análise Faunística de moscas-das-frutas (Diptera: Tephritidae) na Região Oeste de Santa Catarina. Neotropical Entomology, vol. 32, no. 3, p. 421-426. http://dx.doi.org/10.1590/S1519566X2003000300006

MARSARO JÚNIOR, AL., RONCHI-TELES, B., BARBOSA, RI., SILVA-JÚNIOR, RJ., AGUIAR, RM. and SILVA, RA., 2011. Conhecimento sobre moscas-das-frutas no Estado de Roraima. In SILVA, RA., LEMOS, WP. and ZUCCHI, RA. (Eds.). Moscas- 
das-Frutas na Amazônia brasileira: diversidade, hospedeiros e inimigos naturais. Macapá: Embrapa Amapá. p. 279-290, 299 p.

MORAES, RCB., HADDAD, ML. and REYES, AEL., 2003. Faunistic analysis software - AnaFau. In: Anais do VIII Simpósio de Controle Biológico - Siconbiol, 2003. São Pedro. p. 195. Resumos.

RAFAEL, JA., 1991. Insetos coletados durante o Projeto Maracá, Roraima, Brasil: lista complementar. Acta Amazonica, vol. 21, no. 4 , p. 325-336.

RONCHI-TELES, B., ZUCCHI, RA. and SILVA, NM., 1995. Novos registros de espécies de Anastrepha (Dip. Tephritidae) e seus hospedeiros no Estado de Roraima. In Anais do Congresso Brasileiro de Entomologia, 1995. Caxambu: Sociedade Entomológica do Brasil. vol. 15, p. 239. [Resumos...].

RONCHI-TELES, B. and SILVA, NM., 2005. Flutuação populacional de espécies de Anastrepha Schiner (Diptera: Tephritidae) na região de Manaus, AM. Neotropical Entomology, vol. 34, no. 5, p. 733-741. http://dx.doi.org/10.1590/S1519-566X2005000500004

SILVA, RA., DEUS, EG., PEREIRA, JDB., JESUS, CR., SOUZA-FILHO, MF. and ZUCHI, RA., 2011. Conhecimento sobre moscas-das-frutas no Estado do Amapá. In SILVA, RA.,
LEMOS, WP. and ZUCCHI, RA., (Eds.). Moscas-das-Frutas na Amazônia brasileira: diversidade, hospedeiros e inimigos naturais. Macapá: Embrapa Amapá. p. 223-236, 299 p.

SILVEIRA-NETO, S., NAKANO, O., BARBIN, D. and VILLANOVA, NA., 1976. Manual de ecologia dos insetos. São Paulo: Ceres. 419 p.

UCHÔA-FERNANDES, MA., OLIVEIRA, I., MOLINA, RMS. and ZUCCHI, RA., 2003. Biodiversity of frugivorous flies (Diptera: Tephritoidea) captured in Citrus groves, Mato Grosso do Sul, Brazil. Neotropical Entomology, vol. 32, no. 2, p. 239-246. http:// dx.doi.org/10.1590/S1519-566X2003000200008

ZUCCHI, RA., 2000. Taxonomia. In MALAVASI, A. and ZUCCHI, RA. (Eds.). Moscas-das-frutas de importância econômica no Brasil: conhecimento básico e aplicado. Ribeirão Preto: Holos. p.13-24, 327 p.

ZUCCHI, RA., SILVA, RA. and DEUS, EG., 2011. Espécies de Anastrepha e seus hospedeiros na Amazônia brasileira. In SILVA, RA., LEMOS, WP. and ZUCCHI, RA. (Eds.). Moscasdas-Frutas na Amazônia brasileira: diversidade, hospedeiros e inimigos naturais. Macapá: Embrapa Amapá. p. 53-70, 299 p. 
